\title{
UNIVERSITYOF
}

FORWARD

THINKING

WESTMINSTER用

WestminsterResearch

http://www.westminster.ac.uk/westminsterresearch

Social Condensation in the Metropole: Locating the First New Left Beech, N.

This is an accepted manuscript of an article published by Taylor \& Francis in the Journal of Architecture, 22 (3), pp. 488-511.

The final definitive version is available online:

https://dx.doi.org/10.1080/13602365.2017.1321032

(c) 2017 Taylor \& Francis

The WestminsterResearch online digital archive at the University of Westminster aims to make the research output of the University available to a wider audience. Copyright and Moral Rights remain with the authors and/or copyright owners.

Whilst further distribution of specific materials from within this archive is forbidden, you may freely distribute the URL of WestminsterResearch: (http://westminsterresearch.wmin.ac.uk/).

In case of abuse or copyright appearing without permission e-mail repository@westminster.ac.uk 


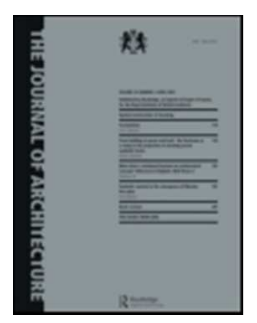

\section{Social Condensation in the Metropole: Locating the First New Left}

\begin{tabular}{|r|l|}
\hline Journal: & The Journal of Architecture \\
\hline Manuscript ID & RJAR-2016-0108.R2 \\
\hline Manuscript Type: & Original Paper \\
\hline Keywords: & New Left, London, social condenser, socialist humanism \\
\hline \multicolumn{3}{c}{ SCHOLARONE ${ }^{\mathrm{M}}$} \\
Manuscripts
\end{tabular}


Nick Beech

\section{Social Condensation in the Metropole: Locating the First New Left}

Figure 1: The New Reasoner, vol. 7 (Winter 1958/59). Cover illustrations by André François.

Figure 2: Universities and Left Review, vol. 7 (Autumn 1959). Cover designed by Germano Facietti, including photograph by Roger Mayne.

Figure 3: At the Partisan Coffee House. Raphael Samuel Archive, Bishopsgate Library.

Figure 4: Douglas Stephen and Partner, Proposed Coffee Bar 7 Carlisle Street, Perspective Sketches, 17 February 1958.

Figure 5: Roger Mayne, 1959. Mary Evans Picture Library/Roger Mayne.

Figure 6: David Hurn, UK. London. Fifties cultural meeting place. The Partisan Coffee-Bar in Soho London. Meeting place of the left wing activists of the period. People in the street outside gaze through the large plate glass window at friends inside. 1957. David Hurn/Magnum Photos.

Figure 7: The Partisan Coffee House, Soho, London, 2nd December 1960. Trinity Mirror/Mirrorpix/Alamy Stock Photo.

Figure 8: Invitation to the opening night of The Partisan. Raphael Samuel Archive.

Figure 9: Telegram from Dorothy and Edward Thompson and John Saville. Raphael Samuel Archive.

\section{[Figures 8 and 9 must be shown together]}

Figure 10: Roger Mayne, 'Trendy Couple', 1959. Mary Evans Picture Library. Mayne regularly contributed to Universities and Left Review and provided six images for Stuart Hall's 'Absolute Beginnings' essay, as well as the cover illustration for the first publication of Colin Mclnnes, Absolute Beginners. 


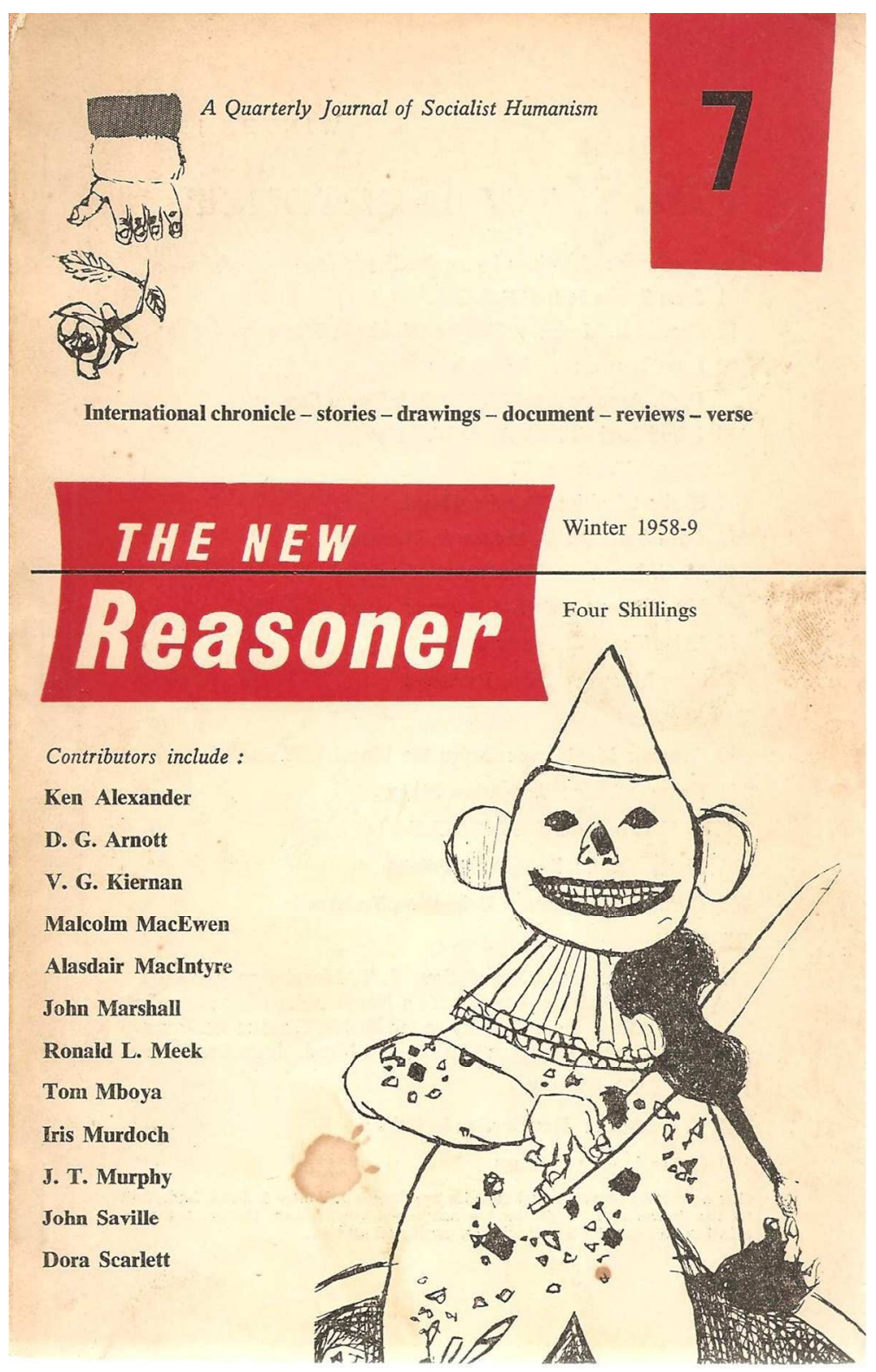

The New Reasoner, vol. 7 (Winter 1958/59). Cover illustrations by André François $381 \times 600 \mathrm{~mm}(72 \times 72 \mathrm{DPI})$ 

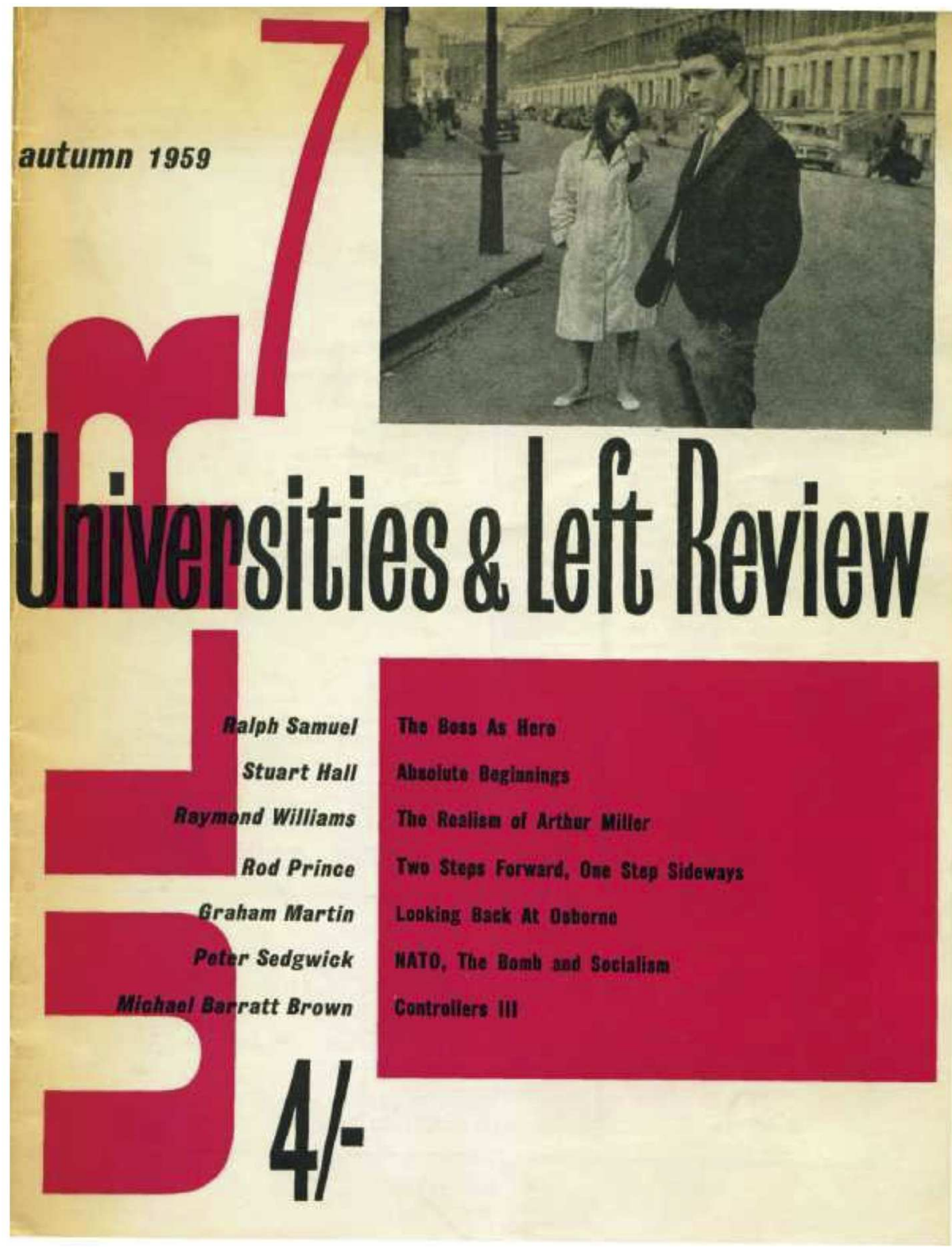

Universities and Left Review, vol. 7 (Autumn 1959). Cover designed by Germano Facietti, including photograph by Roger Mayne.

$214 \times 277 \mathrm{~mm}(150 \times 150 \mathrm{DPI})$ 


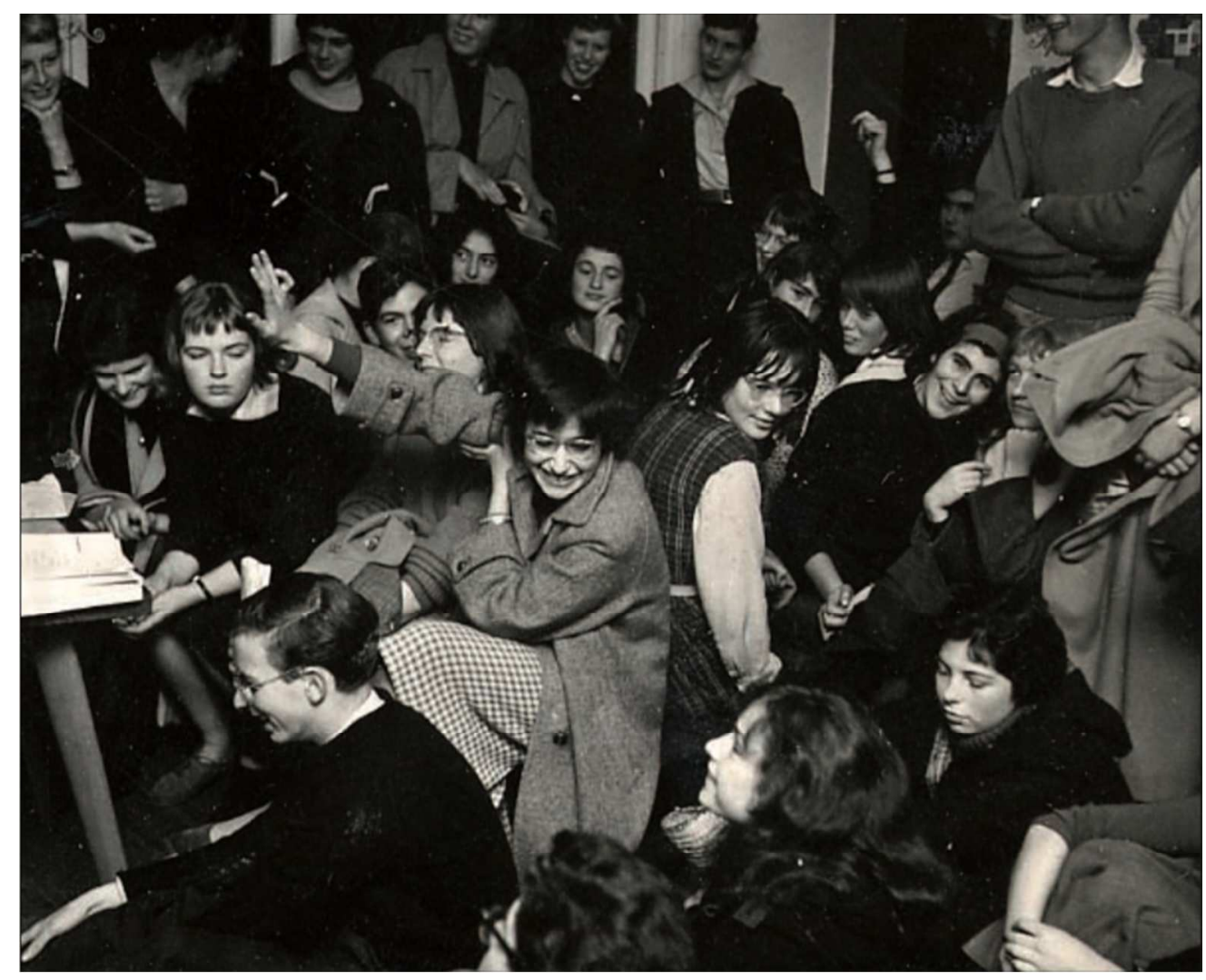

At the Partisan Coffee House. Raphael Samuel Archive, Bishopsgate Library. $324 \times 262 \mathrm{~mm}(72 \times 72 \mathrm{DPI})$ 


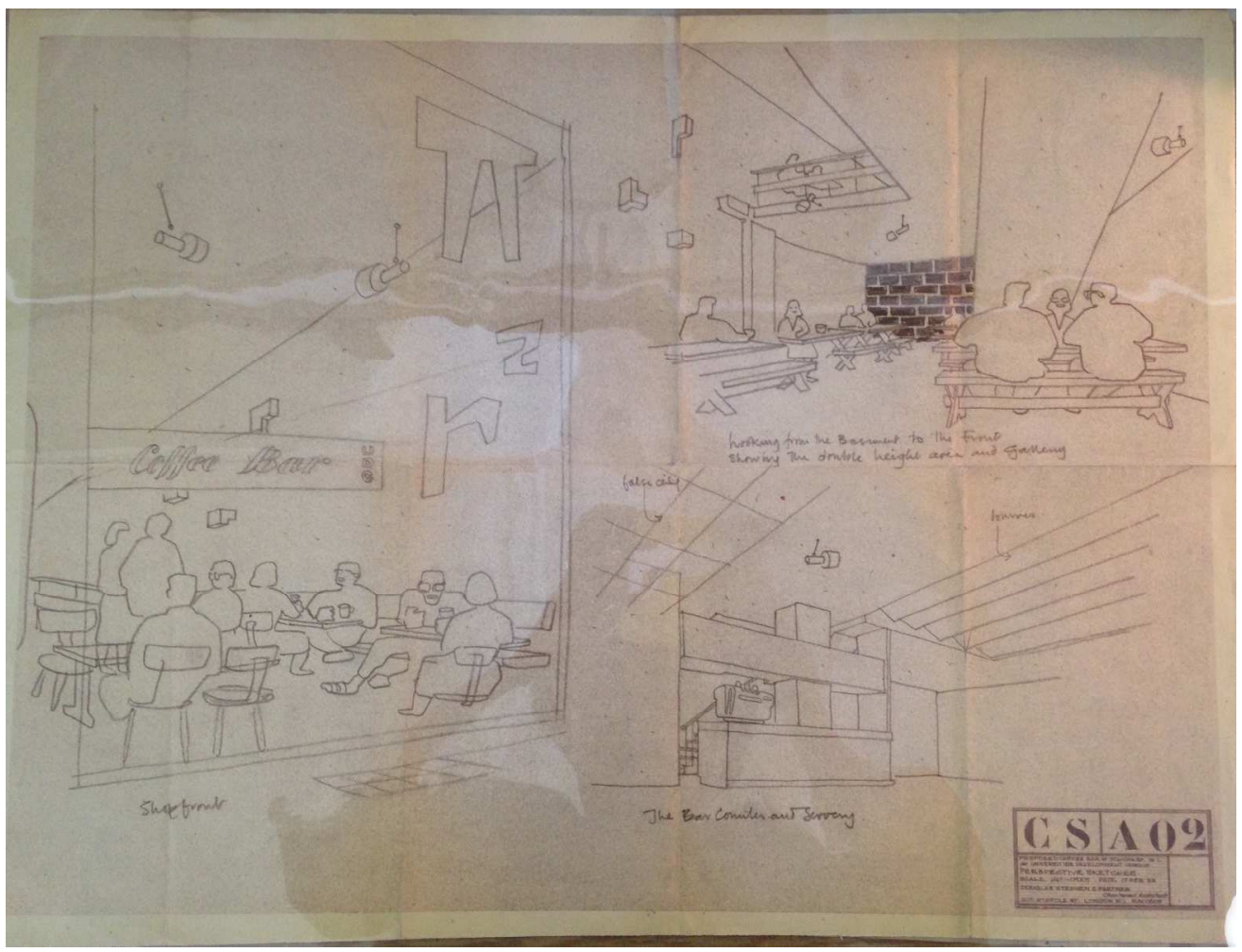

Douglas Stephen and Partner, Proposed Coffee Bar 7 Carlisle Street, Perspective Sketches, 17 February 1958.

\section{$1016 \times 775 \mathrm{~mm}(72 \times 72$ DPI $)$}




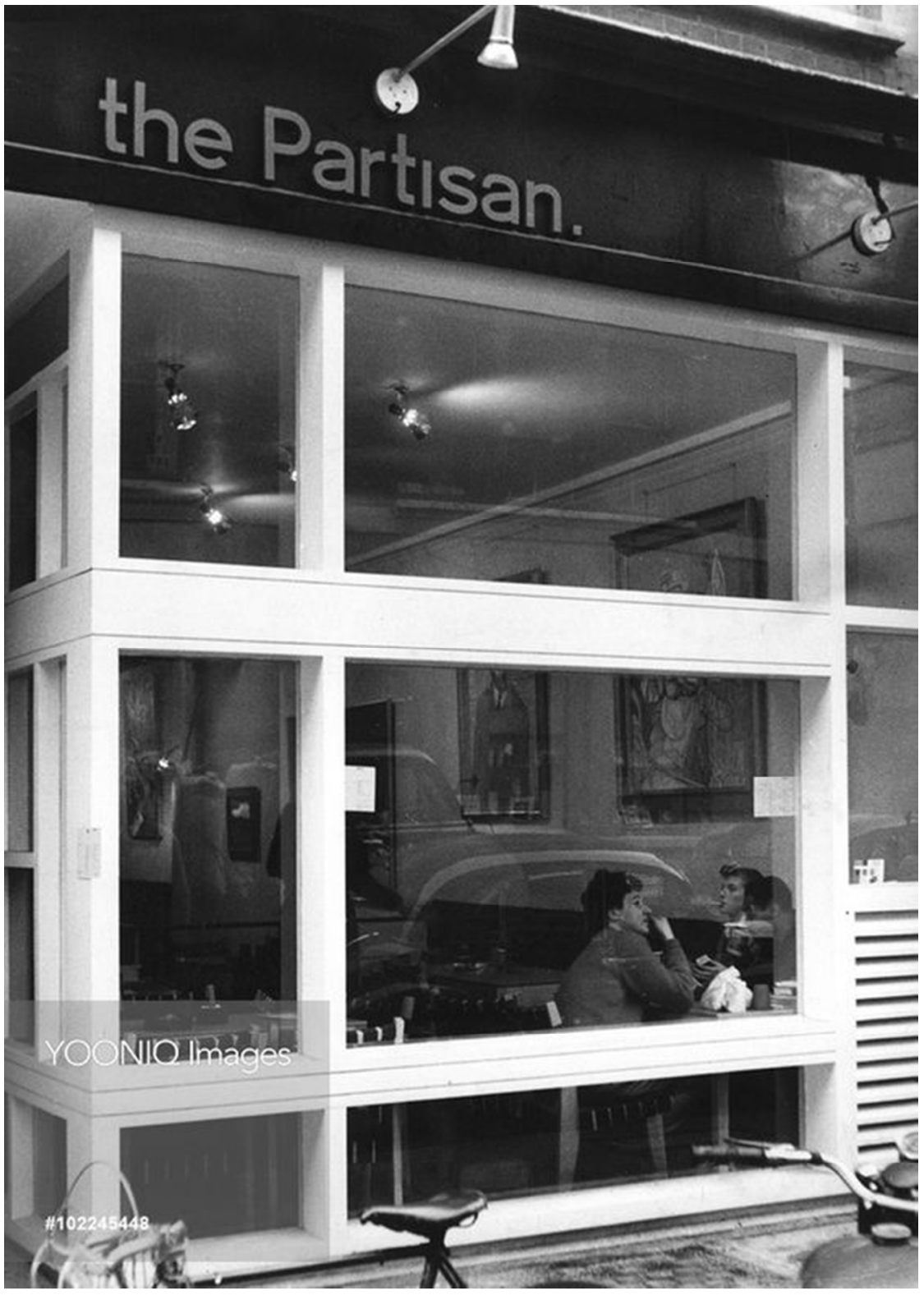

Roger Mayne, Untitled, 1959. Mary Evans Picture Library/Roger Mayne. $198 \times 279 \mathrm{~mm}(72 \times 72$ DPI $)$ 
David Hurn, UK. London. Fifties cultural meeting place. The Partisan Coffee-Bar in Soho London. Meeting place of the left wing activists of the period. People in the street outside gaze through the large plate glass window at friends inside. 1957. David Hurn/Magnum Photos.

$377 \times 248 \mathrm{~mm}(72 \times 72$ DPI $)$ 


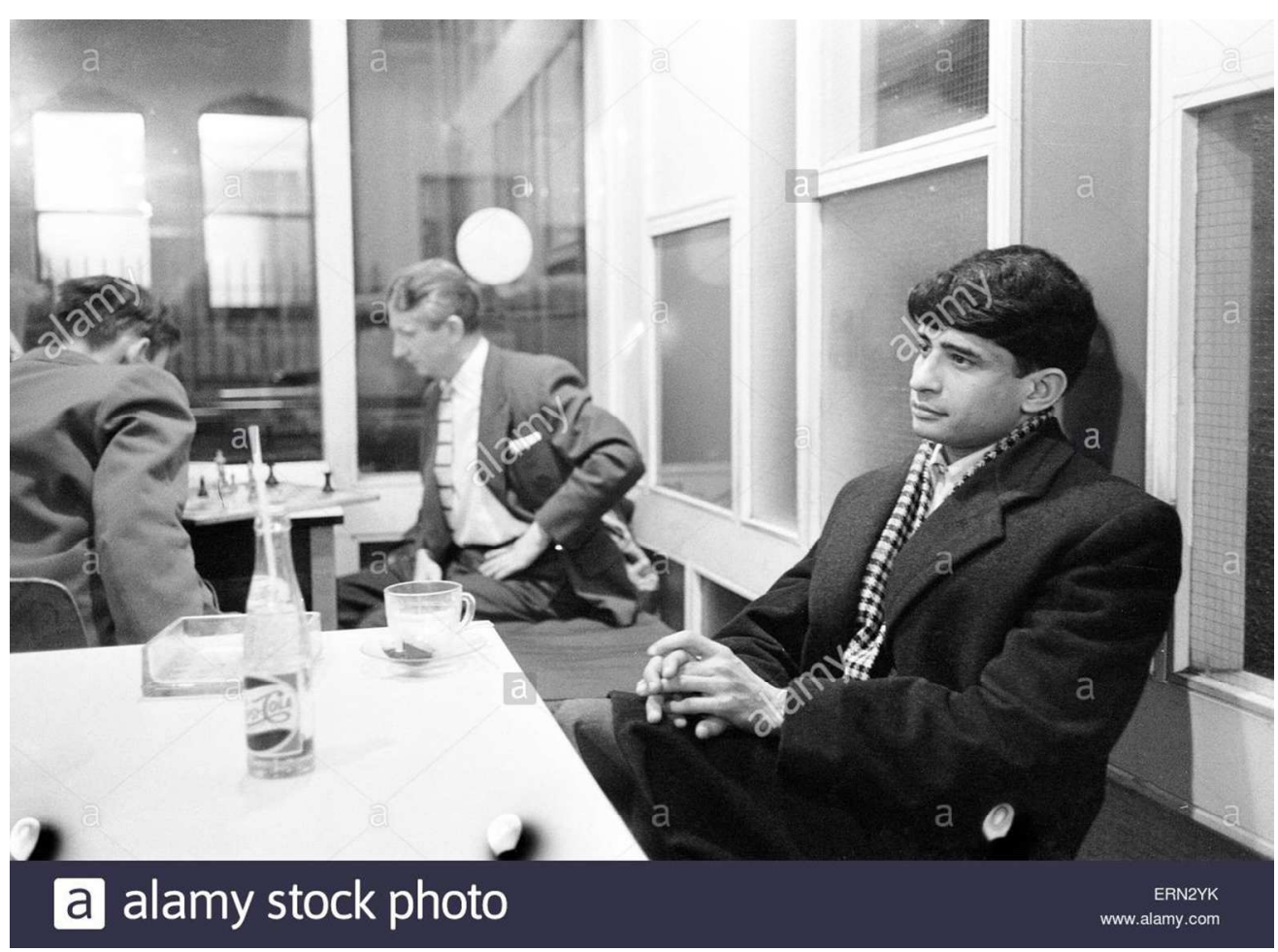

The Partisan Coffee House, Soho, London, 2nd December 1960. Trinity Mirror/Mirrorpix/Alamy Stock Photo. $458 \times 336 \mathrm{~mm}(72 \times 72 \mathrm{DPI})$ 
the Partisan coffee house

7 Carlisle Street Soho Square W1

You are invited to the opening party $5.30-7.30 \mathrm{pm}$ on Tuesday October 21st

rsvp Ralph Samuel the Partisan coffee house 7 Carlisle Street W1

Invitation to the opening night of The Partisan. Raphael Samuel Archive. $1001 \times 654 \mathrm{~mm}(72 \times 72 \mathrm{DPI})$ 


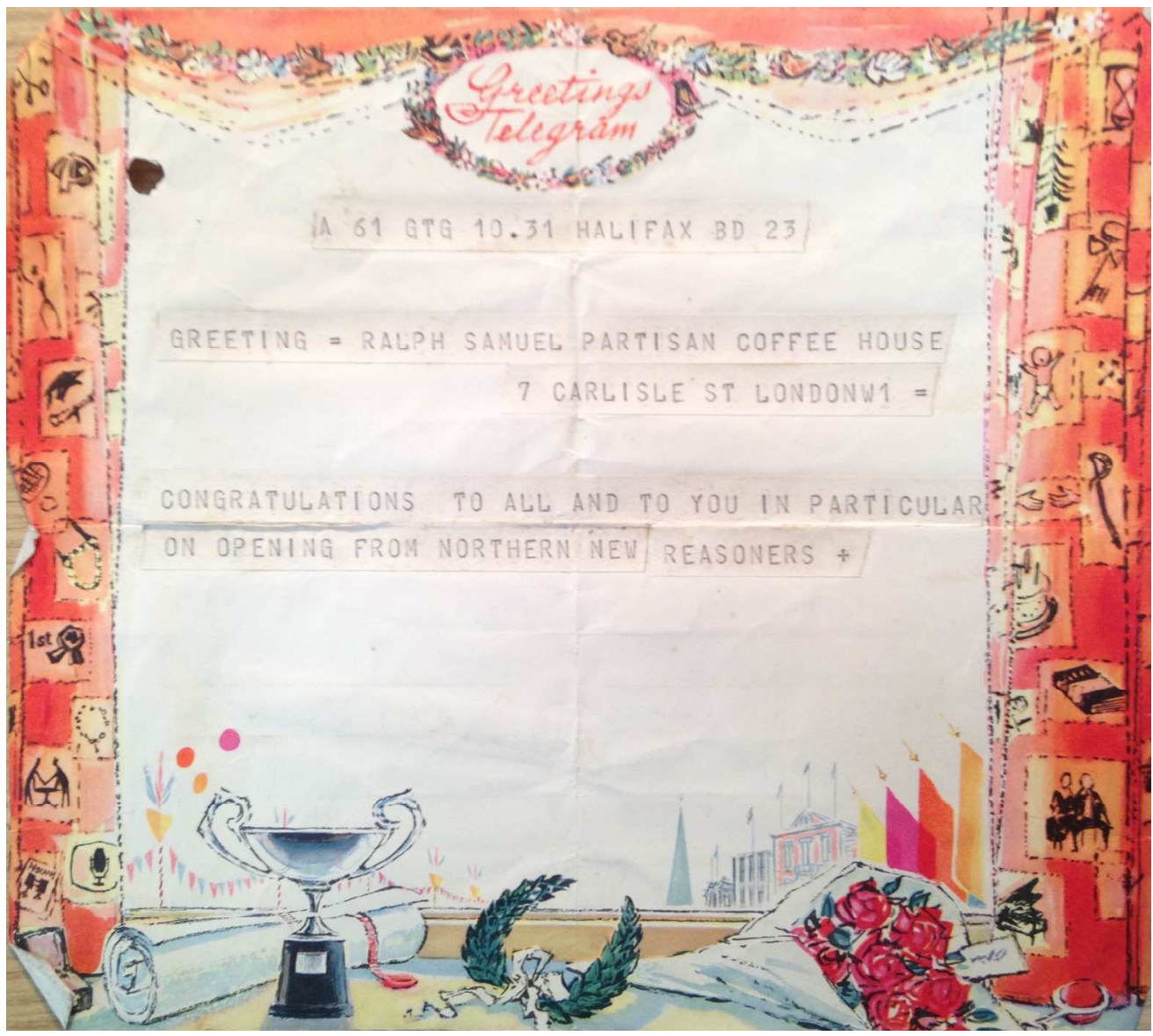

Telegram from Dorothy and Edward Thompson and John Saville. Raphael Samuel Archive.

$899 \times 803 \mathrm{~mm}(72 \times 72$ DPI $)$ 


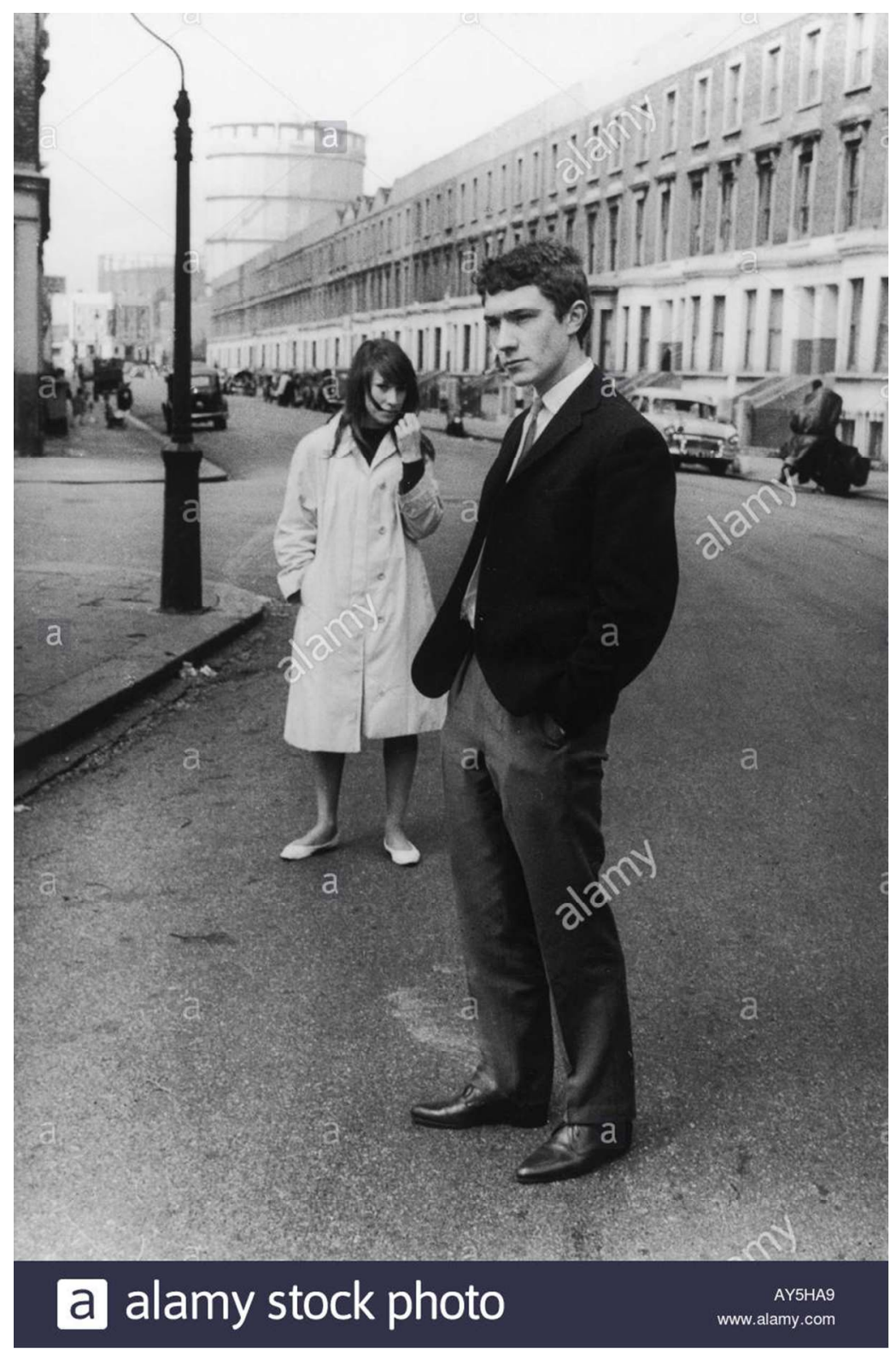

Roger Mayne, 'Trendy Couple', 1959. Mary Evans Picture Library. Mayne regularly contributed to Universities and Left Review and provided six images for Stuart Hall's 'Absolute Beginnings' essay, as well as the cover illustration for the first publication of Colin McInnes, Absolute Beginners.

\section{$321 \times 490 \mathrm{~mm}(72 \times 72 \mathrm{DPI})$}


Social Condensation in the Metropole: Locating the First New Left

\section{Hick}

'But do not think, for goodness sake, that I set out to build a symbol.' Konstantin Melnikov (Summer 1925).

As a proposition, the 'social condenser' assumes a necessary relation between art and society. Just supposing that we could leave aside, for one moment, the vexed question of determination, we might discern in the historiography of the social condenser an excitement that derives from this singular, provisional, social premise: the social condenser does not 'represent' a new social life; the social condenser is not the utility or instrument of a new social life; the social condenser is not an 'expression' or any kind of 'outward appearance' of a new social life. What seems to be proposed with the social condenser is, rather, coterminous with a new social life. What that new social life might be, even the architects of the social condenser were cautious not to fix.

Concerning [this new social life] none can tell us, neither those who have proclaimed it, nor theorists of its development, nor party directives and discipline, for life does not merely depend on such, but on the thousands of small details that quickly disappear from sight. Consequently [...] avenues of investigation may develop diversely, depending on temperament, powers of imagination, the mass of accidentally emerging creative moments, even on words overheard on a bus. And it is possible that every step will be at one and the same time correct and absolutely wrong. ${ }^{2}$

So, what the social condenser might be remains radically open. Still, the social condenser proposes a critical spatial construction, immanent to the transformation of social life itselfa transformation of everyday life, or, in the Russian terminology of the period, a transformation of byt-instituted by the revolution of $1917 .{ }^{3}$ In what follows, I will illuminate this specific, revolutionary Russian Soviet proposition not one bit. 


\section{Page 13 of 35}

The Journal of Architecture

1

2

3

4

5

6

7

8

9

10

11

12

13

14

15

16

17

18

19

20

21

22

23

\section{4}

25

Rather, I want tol will, however, suggest that one can register, in the debates and subsequent historiography of modern architecture in Britain, a similar supposition-that certain forms of architecture and urbanism were appropriate to the post-Second World War welfare state, recognised as a moment of transformation of everyday life. That beyond the specifically 'architectural' (the technical practice of projecting space onto two dimensional planes and providing instruction for building work) a broader set of everyday spatial _. practices were developed in that post-Second World War period-changes in the perception and reproduction of urban space. Further, that these changed perceptions and

reproductions of space in turn produced imaginative, critical responses from political actors, and therefore developed dialectically. ${ }^{4}$ In that sense, the concept of the social condenser acts as a prompt, to reconsider architecture as active (as socially effective, even if not determining) and social action as spatial (as spatially effective). ${ }^{5}$ That aAlongside the 'urban imagination' of the period, we can discern a 'social imagination' in these architecturatat

work in the period, and that these two imaginative planes are imbricateds. ${ }^{6}$

But the horizon of the social imagination of architects and planners at any given historical moment may be extended or truncated in ways altogether distinct from other historical actors. In what follows, I offer a reading of two projects that, strictly speaking, were generated outside the discourse of architecture, but that provoke a reconsideration of both the social and urban imagination of the period. The following presents two minor episodes in the activity of the 'First New Left' (from here 'New Left') and nascent 'cultural studies' in Britain

In the first instance, I will examine how the New Left initiated a specific architectural project-the interior of the Partisan Coffee House-and how this project was informed by, and can be understood in terms of, the moral and aesthetic problems of the New Left. In the second instance, I will examine an emergent condition of urban life in Britain-the racialisation of urban conflict-and how the structure of urban space informed the New Left's responses to that. The Partisan Coffee House, I will argue, was a project analogous to the social condenser in the sense that it sought to generate an active social space. But in examining this space, it is necessary to register the project's limitations, the result of antinomies within the New Left. Thus, the second part, in which the consequences of a

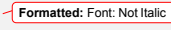


$\underline{\text { changing imperial landscape bearing down on the metropole are shown to affect a new set }}$ of spatial and social problematics for the New Left.

Before doing so, I will briefly set out the broad political position of the New Left in Britain in the period. In presenting the New Left and identifying spatial projects within it, I am less concerned with recovering a hidden history of 'architecture', than to consider how architectural, urban and broadly spatial questions were engaged by the New Left in the late1950s, and in turn how these reveal social transformations that occurred in the period. ${ }^{8}$ In to consider how architectural, urban and broadly'spatial' questions were engaged by the New Left in the late-1950s, revealing social transformations occurring in the period. In particular, I will examine how the New Left imaginatively and practically engaged with the conditions of the primary metropole flondon. In the conclusion I will return to the necessary relation of art and society, and that vexed question of determination.

[Insert Figures 1 and 2 near here]

The First New Left

From 1956 to 1962 intellectuals from across the British Isles developed a platform for deep critical intervention in debates on the nature and status of the welfare state and post-war 'settlement'. This New Left was composed of two initially distinct groups, identifiable through the print forums they established-the group following the New Reasoner: A journal of socialist humanism, edited by Edward Thompson and John Saville, and a younger group following Universities and Left Review (ULR), edited by Stuart Hall, Gabriel Pearson, Ralph (later Raphael) Samuel, and Charles 'Chuck' Taylor. The intellectual history of this New Left has been well covered. ${ }^{9}$ One can identify in that history at least four distinct problematics that exercised those involved, to varying degrees of intensity: a critique of the Communist Party of Great Britain (CPGB) and Stalinism; the elaboration of national

liberation and anti-colonial politics; the development of a pedagogy directed toward class consciousness and liberation; and, a radical development of analytical tools for cultural critique extending from work in English literature (that of F. R. Leavis in particular). Strange, sometimes strained, bedfellows. The origin and development of the New Left has often 


\section{Page 15 of 35}

been framed in purely intellectual terms, producing two distinct results. On the one hand, understanding the New Left as a contradictory development of struggle with (or beyond) Marxism, and producing 'cultural studies. ${ }^{10}$ On the other hand, understanding the New Left as a field of competing, antimonious, incommensurable intellectual positions. ${ }^{11}$

The protagonists of the New Left understood what they were doing in more concrete terms, their undoubtedly intellectual work informed by and predicated upon a practical political project, often presented as a reaction and response to potent world events:

The 'first' New Left was born in 1956, a conjuncture-not just a yearbounded on one side by the suppression of the Hungarian Revolution by Soviet tanks and on the other by the British and French invasion of the Suez Canal zone. These two events [...] unmasked the underlying violence and aggression latent in the two systems that dominated political life at the time-Western imperialism and Stalinism - and sent a shock wave through the political world. In a deeper sense, they defined for people of my generation the boundaries and limits of the tolerable in politics. ${ }^{12}$

The New Left, then, was understood by those who provided its intellectual leadership, as composed of a widespread, socially comprehensive, body of people (a shock wave does not register if felt by only a fraction, a historical conjuncture is not marked by the intellectual pursuits of a minority alone). The main motivation-to develop an alternative to either state socialism or state capitalism, and the main target-imperialism-are also clearly spelled out. What such a short quotation necessarily excludes is the concrete political practices the reaction instituted. And, though rhetorically powerful-and useful for anchoring the 'moment' of the New Left not in a British, but in a global historical context-the emphasis on the punctual events of the conjuncture elides a longer history of political activity (either in national liberation movements in British colonial territories and/or the (PGB), cultural analysis (in essays, novels and poems) and pedagogical engagement (in extra-mural education and the Workers Educational Association [WEA]). Indeed, the intellectual pursuits of the New Left, whether understood as a reformulation of Marxism or an original project of 
cultural studies, is better understood in the context of an ongoing practical political practice. ${ }^{13}$

The central theoretical development for the New Left was a distinct version of humanis Marxism, initiated in a seminal text by Thompson, 'Socialist Humanism'.14 Through a critique of Stalinism, Thompson re-grounded Marxism in a moral supposition -that the 'objective' movement of history does not occur through autonomous structural transformations in economic relations, but rather that any structural transformation in economic relations is produced by individual and collective human action:

Stalinism attempts to short-circuit the processes of social life by disclosing 'economic necessity', by asserting economic, i.e. class, interests as the

only 'real' sources of human motivation [...] Economic changes impe changes in social relationships, in relations between real men and women; and these are apprehended, felt, reveal themselves in feelings of injustice, frustration, aspirations for social change; all is fought out in the human consciousness, including the moral consciousness $[. .$.$] it is precisely the$ element of agency [...] which it is the business of our consciousness to increase. $^{15}$

Thompson's attempt at providing a moral foundation to Marxism drew critical responses from across the New Left at the time. ${ }^{16} \mathrm{His}$ unique version of socialist humanism-clearly drawing on William Morris ${ }^{17}$-subsequently drew the ire of the 'second' New Left in Britain (particularly Perry Anderson) for a failure of conceptual rigour, and it was later, from the mid-1960s, unable to withstand the turn to anti-humanist and structuralist analytical frameworks. ${ }^{18}$ However, developing an argument presented by Madeleine Davis, ${ }^{19}$ I would suggest that treating Thompson's work on socialist humanism as a purely intellectual or theoretical critique of Stalinism distorts his intent, and ignores the contribution made by the wider New Left movement, not through theorization and analysis, but concrete, material practices. As an ethical and moral project, socialist humanism was immanent to this material practice. Davis identifies, in particular, the New Left's engagement with the Campaign for Nuclear Disarmament (CND), the establishment of Left 'Clubs' across Britain, 


\section{Page 17 of 35}

The Journal of Architecture

2

3

4

5

6

7

8

9

10

11

12

13

14

15

16

17

18

19

20

21

22

23

24

25

25

26 and the support of industrial democracy and workers' control. ${ }^{20}$ It is in these key political practices that the possibilities and limits of socialist humanism can be calculated.

I would add to Davis's reading, that a significant corollary to Thompson's version of socialist humanism is strictly materialist in regard to human consciousness-emotions, practices, institutions, techniques, and media, these set the possibilities and limits of consciousness. ${ }^{21}$ Art then becomes the primary site at which consciousness is both exercised and developed, the material site for establishing the horizon of the possible. Thompson's emphasis on art is, in the 'Socialist Humanism' essay, conjoined with a statement on action: that this is not to be deferred-either to a vanguard party or to an auspicious moment in the future-but must always already be available in the lived present, hence the extreme ethical pressure placed on the 'means' by which any putative socialist 'end' is achieved. ${ }^{22} \underline{\text { would suggest }}$ that urban environments, and the architecture of the same, are precisely 'media' through which the possibilities and limits of consciousness are conditioned-architecture, in such a perspective, is not a 'product' of an already conscious, prior, agency, but is, to restate my introductory remarks on the social condenser, coterminous with social life. In this instance, I read Thompson's socialist humanism as remarkably convergent with the aesthetic-political perspective of the proponents of the social condenser.

Thompson's argument was developed within the New Reasoner, which published a number of works of creative writing and some reproductions of visual art. However, it was the other New Left group of the period-the ULR group - who made a concerted effort to engage with new, emerging popular arts of jazz music, cinema, theatre, television, and mass print media. ${ }^{23}$ The ULR group were less concerned with a direct confrontation with Stalinism than with Labourism and Anthony Crosland's revisionist reading of social democracy (influenced by indices of affluence and consumer spending ${ }^{24}$ ) and the structure of the welfare state itself. They were also as influenced by Raymond Williams - whose studies Culture and Society (1958) and The Long Revolution (1961) were treated as of signal importance-and Richard Hoggart's Uses of Literacy (1957) as they were by Thompson. ${ }^{25}$ 
ULR also paid significant attention to questions of architecture-a number of articles in ULR, including those by architects working at the London County Council (LCC) Architect's Department, critique the condition of planning and architecture under the welfare state. ${ }^{26}$ These follow lines of criticism that are-were well known in architectural discourse at the time and in subsequent architectural historiography-the continuation of speculative building; misunderstanding and incoherent responses to the different kinds of metropolitan town, rural and countryside environments; dominance of reductive, sociological statistical modelling and space planning based on slum analysis; abandonment of progressive modern architecture and constructional technology-these criticisms all echo those critiques presented in the pages of Architectural Review in their 'Townscape' and 'Outrage' campaigns. ${ }^{27}$ These won't be examined in detail here, having less to say about the actual spatial conditions the New Left constituted and were constituted within-the environments, the sites, the locations which informed and were produced by New Left material activity.

Thompson was uncomfortable with many of the emphases and interests of the ULR group. He was scathing of the contributions made to ULR by the architect Gordon Redfern. ${ }^{28}$ And he was critical of the influence exerted by both Hoggart and Williams on the younger ULR group-anxious about the particularism of Uses of Literacy and political ambivalence of Hoggart and the absence of political conflict and struggle presented in Williams's conception of culture as a 'whole way of life' that transcended the particularities of class. ${ }^{29}$ Nevertheless, Williams's intellectual project in particular, shared many of the features of socialist humanism as presented by Thompson, in attempting to grasp the concrete, lived dimension in which historical action is produced:

We can learn a great deal of the life of other places and times, but certain elements, it seems to me, will always be irrecoverable. Even those that can be recovered are recovered in abstraction, and this is of crucial importance. We learn each element as a precipitate, but in the living experience of the time every element was in solution, an inseparable part of a complex whole. ${ }^{30}$

This was offered by Williams as a provisional statement in 1961 as to what a study of culture, in an expanded sense, entails. We can note the stress that Williams places on a 


\section{Page 19 of 35}

The Journal of Architecture

1

2

3

4

5

6

7

8

9

10

11

12

13

14

15

16

17

18

19

20

21

22

23

24

25

26

27

28

29

30

31

32

33

34

35

36

37

38

39

40

41

42

43

44

45

46

47

48

49

50

51

52

53

54

55

56

57

58

59

60 concrete located-ness of culture. In addition to Thompson's 'Socialist Humanism' essay, we can utilise Williams' statement as a guide to the analysis of New Left spaces in the period: that is, not to seek a distinct attitude toward 'architecture' or 'planning' within the New Left, but to determine the spatial conditions (an aspect of the 'culture') afforded by the welfare state, and how the New Left sought to determine the possibilities and limits of those spaces for proving the ground of a new politics - not as theoretical exercises, but as practiced. To develop this requires examination of the 'spaces' themselves.

[Insert Figure 3 near here]

Samuel and The Partisan Coffee House

The idea of calling a meeting of [ULR] journal readers in London to hear [Isaac] Deutscher speak-the beginning of the New Left Club movementwas also [Samuel's], as was the layout of the room we hired for the occasion in a Bloomsbury hotel: casually arranged for informal political exchange around tables for about sixty people, in a style, [Samuel] assured us, somewhere between the Parisian Left Bank cafe and the inter-war Berlin cabaret scene. When we returned from a leisurely Indian meal, 700 people were standing impatiently in a queue outside. ${ }^{31}$

In recollections of the various kinds of public event-political and cultural-developed by the New Left, and particularly those conceived by Samuel, there is often related a sense of surprise, excitement, and not a little confusion. The Left Clubs (only later 'New Left Clubs', and in this instance 'ULR London Club') had a longer history than is recalled by Hall here. ${ }^{32}$ Yet this first 'ULR Club Open Meeting', on 5 April 1957, at which Deutscher would provide an introduction to the topic 'Russia in Transition' at the comfortable Royal Hotel, Woburn Place, was the kind of Club that became associated with the New Left.

The references to the 'Parisian Left Bank' and the 'Berlin cabaret' were intended to evoke a cosmopolitanism that Samuel actively sought to foster within the New Left-against the default anti-intellectualism and parochialism of the English (particularly Oxford) establishment. At the same time, the spatial layout-in its informality, clustering of shared 


\section{Page 21 of 35}

The Journal of Architecture

1

2

3

4

5

6

7

8

9

10

11

12

13

14

15

16

17

18

19

20

21

22

23

24

25

26

27

28

29

30

31

32

33

34

35

36

37

38

39

40

41

42

43

44

45

46

47

48

49

50

51

52

53

54

55

56

57

58

59

60
10

a new shopfront in glass [...] seating [...] arranged primarily at the front [...] the central section predominantly used for circulation, and to one side a double height arrangement which serves the purpose of making it quite clear that there is a basement or lower section to the Coffee Bar which can be used when the upstairs part of the Bar is full up and also, in cases when the premises are used as a meeting hall. In this case, a speaker, standing on the platform, shewn on the drawing, could be seen from every part of the ground floor and basement $[. . .]^{40}$

The architect further proposed an 'achromatic colour scheme', and lighting that would provide 'definite chiaroscuro' effects, emphasising 'the double height area by means of a three dimensional mural arrangement'. The scheme indicated a ground floor capacity of seventy, a basement capacity of 120 . The furniture provided large, comfortable chairs and broad tables, with room to work on papers and read. The architects took the brief-that this was to be an 'anti-expresso bar'-to heart, neither emphasising the 'wares', nor attempting to encourage rapid footfall through the café, but instead providing a frame for the visitors themselves. The completed design was rational, minimal and modernist (see Figures 5, 6 and 7) and itt is's clear in the proposal that the architects were navigating between a design request for something 'modern' and a strictly limited budget. ${ }^{41}$

[Insert Figure 5, 6 and 7 near here]

Coupled with Samuel's eclectic pan-European menu-'Old Fashioned Pea Soup' is probably the least dangerous, from the menu, 'Liver Dumplings' perhaps the more adventurous-the astoundingly poor quality coffee, Hall would later recall, drove him to escape from the

offices above, and retreat to one of the very many alternative espresso bars in the area. ${ }^{42}$ The Partisan sought to attract, and succeeded in attracting, many who would otherwise have nowhere to go-by day the homeless and by night those avoiding police. ${ }^{43}$ The ULR Club-later, subsequent to merger with the New Reasoner in 1959, the London New Left Club - used The Partisan as a venue to hold a range of different political and cultural events. These included poetry and literature evenings, theatre, art exhibitions, music (folk, jazz, and 
It was, as Samuel had intended, a cosmopolitan space. However, a key constituency that the ULR Club hoped to reach-the working class-failed to engage, and the political efficacy of The Partisan-in galvanising and directing a New Left programme-remained deeply ambiguous if not entirely ambivalent. It was an outright commercial failure, collapsing within four years in $1962 .{ }^{44}$ Samuel had persuaded his fellow editors on ULR that The _ Partisan would provide financial support for the journal. Instead, it had caused near financial ruin for those involved, and the draining of good-will from those who had stumped up the initial loan-many of whom were highly influential cultural and political operators. Eric Hobsbawm - who had been persuaded by Samuel to join a board of directors to the scheme-recalled the project with unvarnished scorn:

It was a scheme designed for disaster. The then current fashion among architects preferred austere interiors looking like station waiting rooms. These attracted the more demoralized bums and the fringe hangers-on of Soho, who were neither welcomed in nor attracted by establishments with a more elaborate décor [...] Only nostalgia and the need to maintain contact between the pre- and post-1956 generation of the left can explain why I found myself involved in this lunatic enterprise. ${ }^{45}$

The ULR group itself, even those opposed to Samuel, would later recall The Partisan with far | less antipathy than Hobsbawm. But when The Partisan is discussed in the historiography of the New Left it is treated either as exemplary of organisational and financial failure, or more simply as a distraction. I shall would suggest an alternative summary of The Partisan Formatted: Font: Not Italic Formatted: Font: Not tralic environmentin conclusion.

The practical problem-how to generate profit from an anti-commercial enterprise-cannot be denied. =lit seems more than unlikely that The Partisan would ever financially sustain the New Left. But Hobsbawm's visceral dislike of the project, particularly its architecture, seems rather contradictory-surely he did not mean to suggest that The Partisan should have been dressed in the 'amateur exoticism' of the commercial coffee shops of London in

\section{Fo} Formatted: Font: Not Italic 


\section{Page 23 of 35}

The Journal of Architecture

1

2

3

4

5

6

7

8

9

10

11

12

13

14

15

16

17

18

19

20

21

22

23

24

25

26

27

28

29

30

31

32

33

34

35

36

37

38

39

40

41

42

43

44

45

46

47

48

49

50

51

52

53

54

55

56

57

58

59

60

the period? $?^{46}$ From Redfern's response to the brief, and from the photographic record, The Partisan design seems extremely well suited to its purpose, and one can easily imagine possible commercial success for the project (disregarding the catering).

The real contradiction lies in the motivations of Samuel and his understanding of the direction of travel for the New Left. On the one hand, the stark, bare, 'waiting room' of The Partisan is entirely appropriate to Samuel's desire for a modern, cosmopolitan and open movement-the 'space' of the Partisan required constant activation through events: speakers, musicians, visual artists. In that sense, Samuel's vision, and the realisation of the architecture of The Partisan align closely with the social condenser itself. Those who attended The Partisan events were not 'spectators' but active agents in generating the environment, in participating in the formation of a political milieu.

But this 'openness' belied a specific intent harboured by Samuel for the New Left-to sustain and recover where necessary, a particular culture of working class radicalism, linked through a historical chain from the twentieth century to the nineteenth, eighteenth, and seventeenth centuries, the history of British radicalism first fostered by the Communist Party Historian's Group (including Hobsbawm, and Christopher Hill, Samuel's PhD supervisor at Oxford). Hobsbawm articulates the disappointment of this strand of the New Left, in the attraction to The Partisan of a reactionary, conservative working class, of distracted youth sub-cultures, and of a wider 'lumpen proletariat' or underclass. In that sense, perhaps Hobsbawm was right: The Partisan was doomed to failure, precisely because the architecture did contradict the deep motivations of Samuel for the New Left.

But what if both Samuel and Hobsbawm-generator and detractor-were unable to recognise that the culture of the working class and the urban environment of London were undergoing fundamental transformations, and that the contradictions of The Partisan were mmanent to these transformations? Someone sensitive to such a possibility (quite apart from his concern for the financial well-being of the New Left) was Stuart Hall.

[Insert Figures 8 and 9 side by side near here]

.




\section{Page 25 of 35}

The Journal of Architecture

1

2

3

4

5

6

7

8

9

10

11

12

13

14

15

16

17

18

19

20

21

22

23

24

25

26

27

28

29

30

31

32

33

34

35

36

37

38

39

40

41

42

43

44

45

46

47

48

49

50

51

52

53

54

55

56

57

58

59

60
14

importantly because of the way it demonstrates the necessarily 'uneven development' of the change:

In the area of south London where I live, old and new physical environments coexist within a single borough. Here are the old two-storey brick dwellings of a working-class suburb, row after row in a dark street butting straight into the warehouse, lumber yard or factory gate: there are the new eight-storey flats of an LCC housing estate, enclosed in a grassand-concrete jig-saw, offering the beginnings of a 'contemporary' urban facade. Along the Brixton Road, the barrow boys are hawking goods outside a 'utility' style British version of the supermarket. Some of the local children go to school at a Dickensian brick building constructed-and hardly retouched-since the 1880 's: but not far away is the glass and steel compound of the local Comprehensive, not yet completed. ${ }^{51}$

Hall did not simply reside in this area of London. In this period he had left his doctoral studies in Oxford-abandoning a study of the 'international question' in the work of Henry James, examining identity and the cultural confrontations of the 'Old World' and the 'New's2 -and moved to London to work on the editorship of ULR and the political project of the New Left. ${ }^{53} \mathrm{I}$ his late reflections on the period, Hall presented London as a privileged site for his imaginative horizon, a 'sign'-along with New York, jazz music, and American cinema - of modernity, distant from the psychic and social (racialized) binds of colonial Jamaica, opening a realm of new possibilities. ${ }^{54}$ The personal and political tensions that resulted from Hall's confrontation with London as metropole-the moment of recognition in the heart of empire, re-bound within a racialized dynamic once more-was as an acute experience for him as it was for a generation of Caribbean migrants. ${ }^{55}$

This was also the location for a new job.

So I thought well, what can you do? Practically, nothing! I couldn't then drive, so I couldn't drive a milk float. You can teach. So I got a job in a secondary school as a supply teacher [...] at the Kennington Oval, for [...] about three or four years $[\ldots . .]^{56}$ 
Hall proceeds in this recollection to describe travelling between work at the school and work at the ULR-by train from Kennington to the Partisan at the end of the day, and from Soho to the school on a night bus in time for the start of classes. The school was not the 'glass and steel compound', but the 'Dickensian brick building' (a London School Board building), converted into a Secondary Modern. His interviewer-Les Back-then asks about a story he's heard -that Hall had kept an eye on a number of the school students, keeping them safe from racialized violence on London streets.

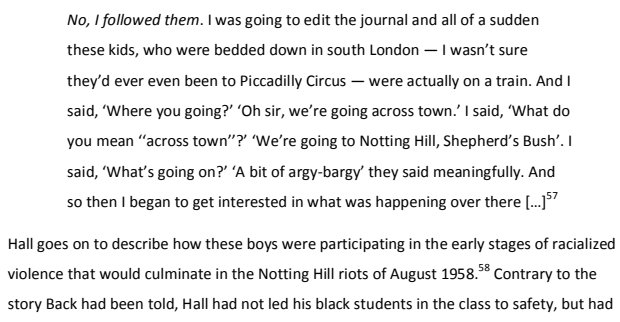




\section{Page 27 of 35}

The Journal of Architecture

the Secondary Modern generation', ${ }^{60}$ Ostensibly a review article of novels by Colin Maclnnes (Absolute Beginners) and E R Braithwaite (To Sir, With Love), a pedagogical memoire by the art teacher Margareta Berger-Hamerschlag (Journey Into a Fog) and an early socio-economic study of youth 'affluence' and consumer spending by Mark Abrams (The Teenage Consumer), 'Absolute Beginnings' is a development of the enquiries first raised in 'A Sense of Classlessness'. ${ }^{\prime 1}$ Here Hall attempts to demonstrate the ways in which class distinctions-and the exploitations that result from such-are entrenched and reproduced by the structure of education in Britain, that the overt 'affluence' of the period disguises the extension of this class reproduction beyond schooling, but that the new 'youth culture' - mods interested in 'sharp' suits, 'cool' jazz, fast money, and identified and portrayed by MacInnes in particular-is evidence of a new set of political identities:

Mr. MacInnes has done this generation more justice than others who have written about the same subject [...] It is the sophisticated advance guard of the teenage revolution who are-at universities and training colleges and art schools and in apprenticeships-the most articulate in their protest about social issues, and who feel most strongly about South Africa or the Bomb. If the cool young men of today were to become the social conscience of tomorrow, it would be because they had seen sights in the Twentieth Century closed to many eyes before. ${ }^{62}$

No doubt, it was claims like this-that both on the surface of a new youth culture, and in the deeper commitments to a new set of political concerns, could be read a new social formation that rankled with Thompson and others within the West Riding of Yorkshire. However, following Hall-both in this observations of the social life of the time, and in his later reflections on his own inner experience-I would argue that a paradigmatic 'space' of the New Left is identified in the urban landscape of the Secondary Modern: one that would result in a new $\mathrm{kind}$ of pedagogical/political project.

[Insert Figure 10 near here]

The Secondary Modern was a key location for the New Left (using Hall here as exemplar of that group) because it was productive of the contradictions of social transformation- 
conflict and change-that the ULR group knew to be wholly ignored by economistic and Labourist arguments dominating debates around the welfare state, that assumed a 'progressive' development-from poverty, toward affluence. But affluence, as Hall put it, would not simply 'melt away' the structures of class domination and exploitation:

It is ridiculous to talk of economic prosperity working, in the natural course of events, to break down established barriers between social classes. Class distinctions based upon attitudes, taste, education, and rooted in the educational system itself, do not wither away any more quickly than the State Department.

Of course, there is a literal, built, constructed, unevenness of 'affluence' in the London described by Hall (affluence itself was not made available to all). But his argument is much deeper-the 'culture' of affluence does not 'erase' these structural conditions either, even when there is access to new consumer goods, new kinds of transport, clothing, music, and so on. In that sense, Hall shares the scepticism toward Croslandite revisionism in the period as Hoggart, or Thompson. It also shares that temporal quality of Thompson's socialist humanism-in which there is an always recurring, re-engagement with the moral present. But Hall recognises this within the imaginative landscape of consumerism in the 1950s, the development of new desires and new obligations (to use the language of Thompson's 'Socialist Humanism'). This imaginative landscape, exercised within the urban environment of London, is both the access point to, and mechanism for acting upon, the deeply problematic metropolitan experience (the racialized violence of Notting Hill but one instance). Hall's sympathetic reading of this imaginative landscape, a product of his struggle with his own social formation, distinguished him at that moment from both Samuel and Thompson, though they shared the same political project. Hall appears to have shared the desires opened by the cosmopolitan culture of modernity in London, but also recognised the radical limits imposed by the metropolitan culture of empire.

Conclusion: spaces of possibility in the metropole

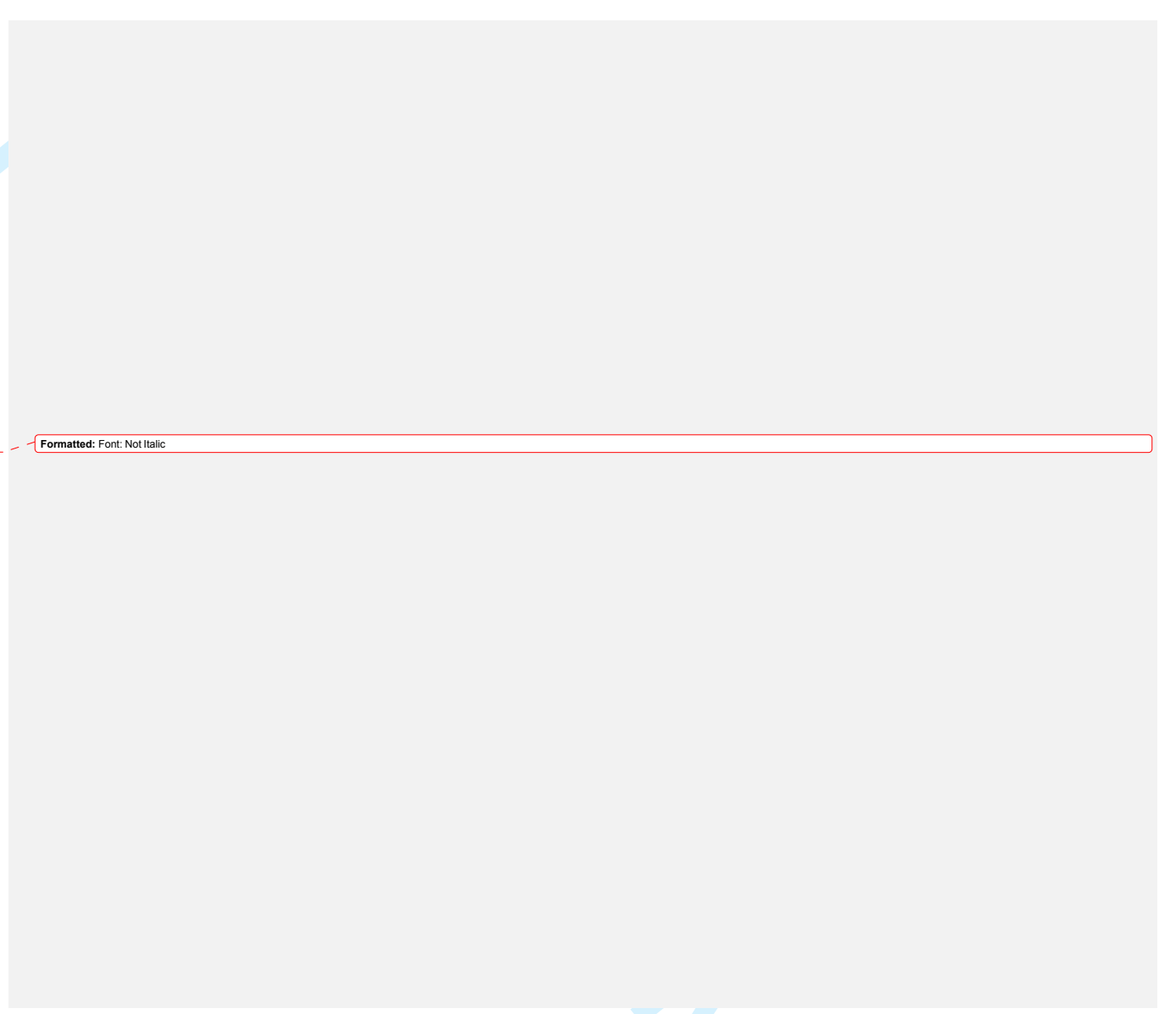




\section{Page 29 of 35}

The Journal of Architecture

To conclude, some observations (further questions) that derive from these brief sketchesof The Partisan and Hall's experience of the Secondary Modern-and some comments on how these could possibly relate (in any sensible way) to 'the social condenser'.

The arguments within the New Left over the Partisan were symptomatic of deep antinomies regarding modernity and the role of Modernism within the New Left. Though these appeared to rest on certain aesthetic qualities-the reductive waiting room' of the design-they in fact attended to the 'organic' or 'inorganic' relation of the design to the New Left itself. It was not Modernism per se that was at stake (in whatever form that might take), as the constituencies to which that Modernism was supposed to respond to and excite. On the one hand, the arguments illuminate how a lingering distrust of populist commercial culture-as opposed to the 'popular' culture emergent from working class selfdetermination and struggle celebrated by Thompson and Hobsbawm, for example-cut into and across perspectives. This is exemplified in Hall's own position: that commercial culture provided the very material in which and through which new social formations were being constructed, shattering any lingering coherence in working class culture. However, where a social critic such as Hoggart perceived in this cultural transformation a necessarily negative movement, Hall was able to identify certain political potentialities. An all too easy assumption is that these antinomiesis reflects a geographical axis - between those members of the New Left of the industrial north those based in London. $^{63}$

But the question of popular culture and modernism was deeper, more fraught, going beyond geographic 'locations' of the New Left, and toward 'locations' within a social formation. Hilarious as the paradoxical history of Tthe Partisan can seem (to establish an anti-commercial commercial space that contests populism through popular arts housed in an elite modernist interior), the arguments play through the problem of political strategy in confrontation with the field of 'culture'. In particular, the different responses to Ithe Partisan-Samuel's advocacy, Hobsbawm's outright rejection, Hall's criticisms - highlight _ how the New Left sought to establish a socialist politics within the contradictions of the welfare state 'settlement' of which they were a part-in which material social conditions (of the city and its infrastructure for example) were already over-encoded with cultural

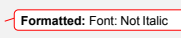

Formatted: Font: Not Italic 
significations. Many, including Hoggart and Thompson-who otherwise held completely distinct political positions (Hoggart a left social democrat, Thompson a left socialist)-were highly critical of populist metropolitan culture as corrosive, and thereby excluded that

culture from strategic consideration. Others, including Hall, Samuel and Williams sought to positively engage the new imaginative landscape of popular youth culture, I would argue precisely because they were already 'dislocated' within the metropole.

This is made clear in Hall's attempt to both think through and practice a New Left pedagogy in the Secondary Modern school. There he recognized that the welfare state in Britain had produced a contradictory space of possibility. Hall recognises the disaffection and dislocation of the colonial immigrant-himself, but foremost the communities of Notting Hill and the black children in his class - but he also recognises the disaffection and dislocation of the child of the 'mother country'-who draws on tropes from cinema, popular music, print media, and mobilises these in the imaginative construction of a 'home' under threat from an 'outside'. Both figures become dislocated in the spaces of the welfare state metropole, and both figures must contend with the absolute limitations placed upon them by the material and social structures in which their consciousness is exercised. The New Left political project for Hall-in his pedagogical practice (and later with work within the Notting Hill Left $\left(\mathrm{Club}^{64}\right)$-was to show how a set of urban problems had become racialized, that this racialization was neither 'natural', nor purely 'ideological', but lived and practiced and open to contention and transformation.

Neither Tthe Partisan, nor Hall's teaching in the Secondary Modern in Kennington, can be said to act as 'social condensers' in the vanguardist sense that the term has so often been used to denote-a spatial technology that institutes or catalyses a new social life. However, returning to the introduction to this essav, if we treat the social condenser as a critical spatial practice immanent to social transformation, they are indeed analogous. practice of those spaces, can be said, I think, to constitute 'condensations' in the sensel suggested at the beginning.-Following Williams, I would argue that these spatial practices theyrepresent experiences 'in solution' rather than in 'precipitate', not 'means' towards specific 'ends', but lived moments. All well and good, one might sav, but we we not leftare left with a problem here=the problem of determination. Williams's formulation of

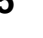




\section{Page 31 of 35}

The Journal of Architecture

2

3

4

5

6

7

8

9

10

11

12

13

14

15

16

17

18

19

20

21

22

23

24

25

'culture' in 1961, from which I have derived this notion of 'condensation' and which I have tried to show is both useful for thinking about the spaces of the New Left, and was itself a product of those spaces, was made as part of a wider analytical proposal-that one might discern a 'structure of feeling' at any given historical moment. ${ }^{65}$ But Williams's analytic at that momentelides any consideration of 'determination' - culture is presented as a 'whole way of life', which cannot be grasped if determinates are abstracted out.

The key argument made by Thompson about Williams's proposition was precisely targeted at this absence of a determination of culture (Thompson forcefully arguing that culture should be understood as a 'whole way of struggle') - for without it, without consideration of the relation between 'art' and 'society', in what sense might the New Left act politically at all? How might it be prevented from falling apart into incommensurate individual positions on the one hand, and on the other, erecting an ahistorical 'ideal' culture above and beyond collective political action? The arguments over the critical spatial practices of the New Left offer the evidence of both an emerging understanding of this complex problem, and, in the end, the absence of an adequate response. Such would have to wait until the 1970s, when both Hall and Williams would engage with the question through distinct readings of Antonio Gramsci. ${ }^{66}$ In this later 'theoretical' work, Hall and Williams would set out a field of concepts for the further development of New Left political practice, resting on the concept of 'hegemony'. ${ }^{67}$

The value of holding on to those spaces produced in the late-1950s, as part of a radical history (i.e. one that informs political work today), is that they recall a trajectory that lies in the heart of socialism and can be captured within the sign of modernism-not the trajectory of progress, ever bound to looking backward, but instead the future tense of possibility.

Konstantin Melnikov, "USSR Pavilion," in The Avant-Garde: Russian architecture in the twenties, ed. Catherine Cooke, a special issue of Architectural Design, 9-10 (1991): 31. Originally published in Le Bulletin de la Vie Artistique, 1925.
2 Aleksander Pasternak, "Novye formy sovremennogo žil'ja," Sovremennaja architektura, 45 (1927): 125-43 (126), as translated and cited in Hugh D. Hudson Jr. "The Social Condenser of Our Epoch'. The Association of Contemporary Architects and the creation of a new way of life in Revolutionary Russia," Jahrbücher für Geschichte Osteuropas, 4 (1986): 557-58 (560). 
${ }^{3}$ On the meaning of byt, see Victor Buchli, An Archaeology of Socialism (Oxford: Berg, 1999), 23-39; and, Christina Kiaer, Imagine No Possessions: The socialist objects of Russian Constructivism (Cambridge MA: MIT Press, 2005), 53-71.

Iuse the term 'spatial practice' in reference to the work of Henri Lefebvre, The Production a space, trans. by Dona' Nots ben and Architecture: A place between (London: IB Tauris, 2006). 5 The necessary dialectics between everyday life, art, revolutionary praxis, and urban space can't be adumbrated here, but see John Roberts,
praxis and the fate of cultural theory (London: Pluto Press, 2006

On the idea of an 'urban imagination' in the period, see John R. Gold, The Experience of M.

The 'first' New Left in Britain was soon distinguished from a 'second' New Left, usually marked with the assumption of editorial control over New Left Review by Perry Anderson in 1962. The British New Left was necessarily distinct, but related to, the various 'New Lefts' of Europe and North America. See, Stuart Hall, "The 'First' New Left," in Out of Apathy: Voices of the New Left thirty years on, ed. Oxford University Socialist Group (London: Verso, 1989), ${ }^{11}-38$.

"The following is one part of a collaborative research project developed as part of "British Culture for Architecture, 1945-1975," a collaborative research project initiated byat the Foundation (2014-16).

See, Lin Chun, The British New Left (Edinburgh: Edinburgh University Press, 1993); Dennis Dworkin, Cultural Marxism in Postwar Britain: History, the New Left, and the origins of Cultural Studies (Durham NC and London: Duke University Press, 1997); Michael Kenny, The First New Left: British Intellectuals After Stalin (London: Lawrence and Wishart, 1995); and, Richard E. Lee, Life and Times of Cultural Studies: The politics and transformation of the structures of knowledge (Durham NC and London: Duke University Press, 2004). Dworkin, Cultural Marxism, representative of the former, Francis Mulhern, Culture/Metaculture (London: Routledge, 2000), and Lee, Life and Times representative of

${ }^{11}$ See Kenny, The First New Left, for example.

${ }^{13}$ Mall, "The Life and Times of the First New Left,", 177. Socialist Humanism," Journal of Political Ideologies, 1 (2013), 57-81. See also, Tom Steele, The Emergence of Cultural Studies: Adult education, cultural politics, and the 'English' question (London: Lawrence and Wishart, 1997); Dorothy Thompson, "On the Trail of the Raymond Williams, Politics and Letters: Interviews with New Left Review (London: New Left Books, 1980).

${ }^{4}$ Edward Thompson, "Socialist Humanism: An epistle to the Philistines," The New Reasoner (NR), 1 (Summer 1957), 105-43.

${ }^{16}$ Within the New Reasoner alone, see Tim Enright, "Materialism or Ecclecticism?" NR, 3 (Winter 1957/58), 105-12; Harry Hanson, "An Open Letter to E P Thompson," NR, 2 


\section{Page 33 of 35}

(Autumn 1957), 79-91; Hanson, “How Wild is my Wildness?," NR, 9 (Summer 1959), 98107; Mervyn Jones, "The Moral Wilderness," NR, 9 (Summer 1959), 107-10; Jack Lindsay, "Socialism and Humanism," NR, 3 (Winter 1957/58), 94-102; Alisdair Maclntyre, "Notes
from the Moral Wilderness -1," NR, 7 (Winter 1958/9), 90-100; MacIntyre, "Notes from the from the Moral Wilderness -1, , NR, 7 (Winter 1958/9), 90-100; Macintyre, "Notes from Moral" (Autumn 1957) 92-8; and Th8), $102-4$, Charles Taylor, "Marxism and Humanism," NR, (Summer 1958), 89-106. ${ }^{17}$ Thompson's first major

Thompson's first major work was the biography, William Morris: From Romantic to
revolutionary (London: Lawrence and Wishart, 1955). Socialist humanism as formulated by Thompson recalls the famous passage-'[...] how men fight and lose the battle, and the thing that they fought for comes about in spite of their defeat, and when it comes turns out not to be what they meant, and other men have to fight for what they meant under another name [...]', William Morris, A Dream of John Ball (London: Reeves and Turner, 1888), 31. ${ }^{18}$ See Perry Anderson, "The Left in the Fifties," New Left Review (First Series), 29 (January/February 1965), 3-18; Anderson, "Socialism and Pseudo-Empiricism," New Left Review (First Series), 35 (January/February 1966); Anderson, Arguments Within English Marxism (London: Verso, 1980). On structuralist critiques of humanism, see Richard Johnson, "Edward Thompson, Eugene Genovese aic s ${ }_{19}$ Davis, "Rea

20 lbid, $72-6$.

${ }^{20}$ Ibid., $72-6$

22 'We do not see the socialist movement as merely a movement with a different objective from other political movements: we see it as a different kind of movement [...] in which [..] the objective itself, a society of equals, finds living embodiment.' Thompson, "A Psessay in Ephology," NR, 10 (Autumn 1959), 1-8 (5). See also, Taylor, "Marxism and Humanism," 95. ${ }^{23}$ See for example Lindsay Anderson, "Free Cinema," Universities and Left Review (ULR), 2 (Summer 1957), 48-52; Stuart Hall, "In the No Man's Land," ULR, 3 (Winter 1958), 86-7; Richard Hoggart, "BBC and ITV After Three Years," ULR, 5 (Autumn 1958), 32-6; Rod Prince, "Cinema at a Dead End," ULR, 4 (Summer 1958), 80-1.

C. A. R. Crosland, The Future of Socialism (London: Jonathan Cape, 1956).

Richard Hoggart, The Uses of Literacy: Aspects of working class culture (Harmondsworth Penguin, 1957), Ray The Uses of Lims, Cu: Ase and Sociely, 1780-1950 (London: Chatto and 1961)

See David Gregory Jones, "Housing the City Dweller," , ULR, 1 (Spring 1957), 42-4; John Harlow, "One New Town," ULR, 5 (Autumn 1958), 18-20; Janet Hase, Ellis Salmon and
others, "Impressions of Two New "The Real Outrage," ULR, 5 (Autumn 1958), 7-10; Gordon Redfern and John Smith, "The Crisis in Town Planning," ULR, 2 (Summer 1957), 36-40; and, Graeme Shankland, "The Crisis in Town Planning," ULR, 1 (Spring 1957), 37-42.

See for example, Mathew Aitchison (ed.) Townscape Revisited, a special issue of Journal of Architecture, 5 (2012); and, John Pendlebury, Erdem Erten and Peter J. Larkham (eds), Alternative Visions of Post-War Reconstruction: Creating the modern townscape (Abingdon
and New York: Routledge, 2015). 
${ }^{28}$ See Edward Thompson, "Commitment in Politics," ULR, 6 (Spring 1958), 50-5 (51-2). ${ }^{29}$ See Thompson, "Comstict New Left Review (First Series), 9 (May)/Sune 1961), 24-33, and Thompson, "The Long ${ }_{30}$ Willion (Part 2), New Left Rev ${ }^{31}$ Stuart Hall, "Rang Re Samuel: $1934-96$,

(Feriest), 22 ${ }^{32}$ On the Left Clubs see

On the Left Clubs see Thompson, "On the Trail of the New Left," 99; and, Davis, "Reappraising British Socialist Humanism," 73-4.

the New Left took, refoad demolition of the class structure and organisational form that , efers briefly to the New Left Clubs as a 'milieu', see Sedgwick, "The Two Harmondsworth, 1976), 13idgery (ed.) The Left in Britain, 1956-68 (Penguin: 1976), 131-53, (142). With its emphasis on place the term could usefully ${ }^{34}$ On the structure and operation of the New Left Clubs, see Caroline Bamford, "The Politics of Commitment: The early New Left in Britain, 1956-1962," Unpublished Doctoral Thesis, University of Edinburgh (1983), 286-323.

See, Bishopsgate Institute, Raphael Samuel Archive (RSA), "The New Left," 1957 Correspondence, RS $1 / 002$.

${ }^{37}$ Mike Berlin, "The Partisan Coffee House: Cultural Politics and the Early New Left," Bishopsgate Institute, 8 February 2012

ittp://www. bishopsgate. or uk/20udios aspx?vid=7563 (accessed 21 June 2016) Berlin "The Partisan Coffee House"; and Bamford, "The Politics of Commitment" 295-7. 39 That the history of the Douglas Stephen and Partner practice remains unwritten is Michael Carapetian, British Buildingas, 1960-64(London: Adam and Charles Black, 1965); and 5 tan Allen and Hal Foster, 'A Conversation with Kenneth Frampton', October, vol. 106 2003), 35-58 (pp. 35-8).

${ }^{10}$ RSA, Douglas Stephen and Partner, Letter, 18 February 1958, RS1/101. ${ }^{11}$ Ibid. A contract was secured with Viceroy Builders for a sum of $£ 2,287$ 3s. 6p. RSA Douglas Stephen and Partner, Letter, 22 May 1958, RS1/101.

${ }^{43}$ Berlin, "The Partisan Coffee House"

${ }^{44}$ See Bamford, "The Politics of Commitment," 301 .
The Partisan was rescued by a private individual -Nick Faith-buying out those who were owed from the initial loan Bamford "The Politics of Com mitment" 301.

${ }^{45}$ Eric Hobsbawm, Interesting Times: A twentieth-century life (London: Allen Lane, 2002), 213-14. $213-14$.
46 ypically recognised. See Matthew Partington, "The London Coffee Shops of the 1950s: eclectic challenge to modernist design practices," Unpublished Doctoral Thesis, University of $\frac{\text { Bristol (2008). }}{47}$ Concerns expressed in correspondence with Alan Hall (no relation) in 1957. Stuart Hall, private papers.

Stuart Hall, "A Sense of Classlessness," ULR, 5 (Autumn 1958), 26-32. 


\section{Page 35 of 35}

${ }^{49}$ By placing so much pressure on the category of 'class', the essay drew fire from, among others, Thompson and Samuel. See, Thompson, "Commitment in Politics"; Ralph Samuel, "Class and Classlessness," ULR, 6 (Spring 1959), 44-50. 51 all, "A Sense

${ }_{51}^{51}$ bid.

52 Hall and Back, "At Home and Not at Home," 665-7.

${ }^{54} \mathrm{lbid}$. For a map of both the psychic and social dimensions of the colonial and diasporic see

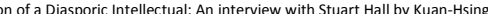
Chen," in David Morley and Kuan-Hsing Chen (eds) Stuart Hall: Critical dialgoues in cultural

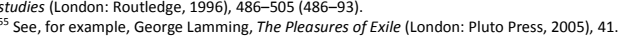
For the significance of London more generally for the black Atlantic diaspora, see Paul Gilroy, The Black Atlantic: Modernity and double consciousness (New York: Harvard University Press, 1995); and, Bill Schwarz "Crossing the Seas," in West Indian Intellectuals in Britain, ed. by Bill Schwarz (Manchester. Manchester University Press, 2003), 1-30. "Hall and Back, "At Home and Not at Home, 67.

57 Ibid. My emphasis.
58 On Notting Hill and the 'race riots', see Edward Pilkington, Beyond the Mother Country: West indians and the Ning Hill Race Riots (London: IB Tauris, 1988).

${ }^{\circ 0}$ Stuat Hall "Absolute

Secondary Modern generation," ULR 7 (Autumn 1959), $16-25$,

There is an interesting relay between Maclnnes and Hall-who were friends - in this concrete cloud-kissers, rising up like felixes from the Olde Englishe squares, and then those gorgeous parks, with trees like classical French salads, and then again the port life down 1959).

${ }_{62}^{1959) .1}$ " “Absolute Beginnings," 25.

${ }^{63} \mathrm{An}$ assumption that was borne by, among others, Hall and Thompson. See Thompson, "Commitment in Politics," and Hall, "Life and Times of the First New Left"

See ULR, 5 (Autumn 1958); and, Mugiko Nishikawa, "Interview with Stuart Hall," edited by Thomas Garza, Grassroots Media Zine, 2 (2014), 17-43.

"See, Stuart Hall, "The 'Base and Superstructure' Metaphor," in Class, Hegemony and Party W. by Jon Bloomfield (London: Lawrence and Wishart, 1977), 43-72; and Raymond Series) 82 (November/December 1973), 3-16. ${ }^{67}$ It will be noted that I interpret the 'cultural studies' of Hall and Williams as a continuation of the political project-necessarily radically altered by the conjunctural conditions of their historical moment-instantiated by the 'first' New Left, and a political practice, not a theoretical exercise or academic discipline. 